\title{
Gene homozygosis and mitotic recombination induced by camptothecin and irinotecan in Aspergillus nidulans diploid cells
}

\author{
GIOVANA N.M. ESQUISSATO, JULIANE R. DE SANT'ANNA, CLAUDINÉIA C.S. FRANCO, \\ LÚCIA J. ROSADA, PAULA A.S.R. DOS SANTOS and MARIALBA A.A. DE CASTRO-PRADO
}

Universidade Estadual de Maringá, Departamento de Biotecnologia, Genética e Biologia Celular, Av. Colombo, 5790, Bloco H67, Sala 21-A, 87020-900 Maringá, PR, Brasil

Manuscript received on March 18, 2013; accepted for publication on February 17, 2014

\begin{abstract}
Mitotic recombination is a process involved in carcinogenesis which can lead to genetic loss through the loss of heterozygosity. The recombinogenic potentials of two anticancer drugs topoisomerase I inhibitors, camptothecin (CPT) and irinotecan (CPT-11), were evaluated in the present study. The homozygotization assay, which assess the induction of mitotic recombination and gene homozygosis, as well as the heterozygous A757//UT448 diploid strain of Aspergillus nidulans were employed. The three non-cytotoxic concentrations of CPT (3.5 $\mathrm{ng} \mathrm{mL}^{-1}, 10.5 \mathrm{ng} \mathrm{mL}^{-1}$ and $17.4 \mathrm{ng} \mathrm{mL}^{-1}$ ) were found to induce both mitotic recombination and gene homozygosis. CPT treatment produced three diploids homozygous, for nutritional and conidia color genes, and Homozygotization Indices (HI) significantly different from negative control. On the other hand, only the highest CPT-11 concentration tested $\left(18 \mu \mathrm{g} \mathrm{mL}^{-1}\right)$, corresponding to the maximal single chemotherapeutic dose, produced HI values higher than 2.0 and significantly different from negative control HI values. The recombinogenic effects of both topoisomerase I blockers were associated with the recombinational repair of DNA strand breaks induced by CPT and CPT-11. The anticancer drugs CPT and CPT-11 may be characterized as secondary malignancies promoters in cancer patients after chemotherapy treatment.
\end{abstract}

Key words: anticancer drugs, homozygotization assay, homologous recombination, secondary malignancies.

\section{INTRODUCTION}

DNA topoisomerase I (Topo I) is an eukaryotic nuclear enzyme that catalyzes relaxation of both positively or negatively charged DNA during multiple cellular process, such as DNA replication, recombination and transcription. The relaxing action of Topo I occurs by nicking a DNA singlestrand and enabling the broken strand to rotate around the Topo I - bound DNA strand. Once the DNA is relaxed, the Topo I reseals the original nick by reversing its covalent binding (Pommier 2006).

Correspondence to: Marialba Avezum Alves de Castro-Prado E-mail:maacprado@uem.br
Topo I is the cellular target of the anticancer drug camptothecin (CPT), a plant alkaloid isolated in the 1960s from the bark of the Chinese tree Camptotheca acuminate. Despite the potent antitumor activity of CPT observed among gastrointestinal cancer patients, the severe adverse effects of this Topo I poison revived the interest in research on CPT analogs as anticancer drugs. The water-soluble CPT derivative, irinotecan (CPT11), which also exerts its antitumour activity by binding to the enzyme Topo I, has been reported to have effective clinical activity against several types of human malignancies, especially colorectal 
cancer (Moertel et al. 1972, Pommier 2006, Punt and Koopman 2008).

CPT and its derivative CPT-11 bind to the Topo I DNA complex, preventing the next DNA religation step. The action of both Topo I inhibitors on the cleavage complex results in the accumulation of the reversible ternary complex consisting of Topo I-camptothecin-DNA. The persistence of the drug-induced cleavage complexes is essential for optimum cytotoxicity of the Topo I inhibitors. This occurs because a fraction of the drug-induced cleavage complexes is converted into DNA doublestrand breaks (DSB) upon collision with replication forks. DSB triggers cell cycle S and G2-M phases arrest, and may be repaired mainly through the homologous recombination repair pathway. The cytotoxicity of Topo I poisons has in fact been related to defects in cell cycle checkpoint pathways and DNA repair (Tanizawa et al. 1995, Arnaudeau et al. 2001, Huang et al. 2008, Pommier et al. 2010).

Homologous mitotic recombination (HR) is a crucial process for both faithful DNA replication in vertebrate cells and DSB repair pathway. HR occurs by the exchange of genetic material either between sister chromatids or homologous chromosomes. Whereas inter-sister HR restores the DNA sequence just as it was before the injury, inter-homologue HR induces the loss of heterozygosity ( $\mathrm{LOH}$ ) of parental markers. Inter-homologue HR may be a prerequisite for the development of tumors, such as hereditary retinoblastoma, in which it is estimated that inter-homologue HR undertakes the loss of the wild-type retinoblastoma allele in approximately $40 \%$ of the tumors. The role of HR in cancer development was also demonstrated in some cancer-prone hereditary diseases like Bloom and Werner syndromes (Saintigny et al. 2002, Payne and Hickson 2009, Moynahan and Jasin 2010).

Heterozygous diploid strains of the filamentous fungus Aspergillus nidulans have been used to evaluate the recombinogenic potential of several chemical compounds (Domingues Zucchi et al.
2005, Cardoso et al. 2010, Santos et al. 2012). A. nidulans is considered a model system for the mitotic crossing-over study because its cells spend the greater part of their cycle in the G2 phase. Since chromosomes are in duplicate at this phase, they significantly favor mitotic recombination (Bergen and Morris 1983, Castro-Prado et al. 2009, Sant'Anna et al. 2009).

Because inhibitors of DNA synthesis and inducers of DNA strand breaks have been described as the most potent inducers of homologous recombination in mammalian cells (Arnaudeau et al. 2000) and taking into account the DNA fragmentation caused by the Topo I inhibitors in human cells (Pommier 2006), this present study investigates the recombinogenic potential of CPT and CPT-11 for their ability to induce gene homozygosis and mitotic recombination in heterozygous diploid cells. In order to achieve our goal, a diploid strain of $A$. nidulans, which is heterozygous for several nutritional markers, as well as the homozygotization assay (Pires and Zucchi 1994), previously used to characterize the recombinogenic potential of several anticancer agents, such as cisplatin and cytosine arabinoside (Miyamoto et al. 2007), were employed.

\section{MATERIALS AND METHODS}

\section{STRAIN AND CULTURE MEDIA}

The master strains A757, with yellow conidia, and UT448, with white conidia, were used to form the diploid A757//UT448 strain of A. nidulans (Roper 1952) (Table I). Since diploid strain is heterozygous for five nutritional markers, it may grow in Minimal Medium (MM), consisting of Czapek-Dox medium, supplemented with $1 \%(\mathrm{w} / \mathrm{v})$ glucose. On the other hand, when growing in the Complete Medium (CM), as previously described by Miyamoto et al. (2007), the diploid strain may originate auxotrophic mitotic segregants. Supplemented Medium (SM) consists of MM supplemented with all the 
nutritional requirements of the strains which form the diploid (Table I), except one in each medium type. Solid Medium contains $1.5 \%(\mathrm{w} / \mathrm{v})$ agar.

TABLE I

Genotype and origin of $A$. nidulans strains.

\begin{tabular}{ccc}
\hline Strains & Genotype & Origin \\
\hline A757 & $y A 2(\mathrm{I})$, methA17 (II), pyroA4 (IV). & FGSC* \\
\multirow{2}{*}{ UT448 } & riboA1 (I), pabaA124(I), biA1(I), & Utrecht, \\
& AcrA1 (II), wA2(II). & Holand. \\
\hline
\end{tabular}

Requirements for: riboflavin $=$ riboA1, p-aminobenzoic acid $=$ pabaA124, biotin $=b i \mathrm{~A} 1$, methionine $=$ meth $\mathrm{A} 17$, pyridoxine $=$ pyroA4. Conidia color: white $=w A 2$; yellow $=y A 2$. AcrA1, resistance to acriflavine. ${ }^{*}$ FGSC $=$ Fungal Genetic Stock Center, University of Kansas Medical Center, Kansas, USA. (I) = linkage group I, (II) = linkage group II, (IV) = linkage group IV.

\section{DRUG TREATMENT}

(S)-(+)-camptothecin (CPT, CAS \# 7689-03-4, $\mathrm{C}_{20} \mathrm{H}_{16} \mathrm{~N}_{2} \mathrm{O}_{4}$, FW 348.4, Sigma-Aldrich Co, St. Louis Mo, USA) dissolved in $\mathrm{NaOH}(10 \%)$, and irinotecan hydrochloride (CPT-11, CAS \# 10028690-6, $\mathrm{C}_{33} \mathrm{H}_{38} \mathrm{~N}_{4} \mathrm{O}_{6}$. HCl, FW 623.14, Sigma-Aldrich $\mathrm{Co}$, St. Louis Mo, USA) dissolved in $\mathrm{NaOH}(4 \%)$, were added to molten $\mathrm{MM}$. $\mathrm{NaOH}$ was per se neither visibly cytotoxic nor recombinogenic for the diploid strain (results not shown). Non-cytotoxic CPT concentrations, $3.5 \mathrm{ng} \mathrm{mL}^{-1}, 10.5 \mathrm{ng} \mathrm{mL}^{-1}$ and $17.4 \mathrm{ng} \mathrm{mL}^{-1}$, that induced micronucleus in Chinese hamster ovary WBL cells (Kirpinic et al. 2005), and non-cytotoxic CPT-11 concentrations, $4.5 \mu \mathrm{g}$ $\mathrm{mL}^{-1}, 9 \mu \mathrm{g} \mathrm{mL}^{-1}$ and $18 \mu \mathrm{g} \mathrm{mL}^{-1}$, corresponding to the chemotherapeutic doses of CPT-11 (Campto ${ }^{\circledR}$ ) (Kašuba et al. 2010), were used in the present study. In the case of toxicity measurements, A757//UT448 diploid colonies' diameters were determined six days after incubation, at $37^{\circ} \mathrm{C}$. The growth rates in the presence (treatment) and in the absence (control) of the anticancer drugs were compared by OneWay Variance Analysis and by Bonferroni posttest, at $\mathrm{p}<0.05$ (results not shown). The anticancer drug cisplatin $\left(\mathrm{Pt}\left(\mathrm{NH}_{3}\right)_{2} \mathrm{Cl}_{2}\right.$, FW 300.1, SigmaAldrich Co., St. Louis Mo, USA), previously characterized as recombinogenic in human colorectal adenocarcinoma cells (Lin and Howell 2006) and in A. nidulans diploid cells (Miyamoto et al. 2007), was used as a positive control.

\section{HomOZYGOTIZATION ASSAY}

Diploid colonies ofA757//UT448 strain were obtained in petri dishes containing MM (negative control), $\mathrm{MM}+$ cisplatin $\left(0.9 \mu \mathrm{g} \mathrm{mL} \mathrm{m}^{-1}\right.$, positive control $), \mathrm{MM}$ + CPT (3.5 ng mL ${ }^{-1}, 10.5 \mathrm{ng} \mathrm{mL}^{-1}$ and $17.4 \mathrm{ng} \mathrm{mL}^{-1}$, treatment 1) and $\mathrm{MM}+\mathrm{CPT}-11\left(4.5 \mu \mathrm{g} \mathrm{mL}^{-1}, 9 \mu \mathrm{g}\right.$ $\mathrm{mL}^{-1}$ and $18 \mu \mathrm{g} \mathrm{mL}^{-1}$, treatment 2) (Figure 1A-D). The petri dishes were incubated for six days at $37^{\circ} \mathrm{C}$ and then visually inspected for diploid sectors arising on the original diploid strains' colonies. Diploids were purified on the MM, individually transferred to the $\mathrm{CM}$ dishes and then processed by spontaneous haploidization. Each diploid produced haploid mitotic segregants which were purified in $\mathrm{CM}$ and then had their mitotic stability evaluated in $\mathrm{CM}+$ benomyl $(0.2$ $\left.\mu \mathrm{g} \mathrm{mL}^{-1}\right)$. Benomyl, an haploidizing agent, is a strong spindle toxin, leading to disturbance in the mitotic segregation of chromosomes (Hüsgen et al. 1999). The mitotically stable haploid segregants at the final stage were the only ones selected for the recombinogenic test. Such segregants were individually transferred to different SM for their phenotypic analyses. The mitotic crossing-over causes homozygotization of heterozygous-conditioned genes. If CPT or CPT11 induces mitotic crossing-over in the original diploid strain, only heterozygotes $(+/-$ or $-/+)$ or homozygotes $(+/+)$ diploids will develop in the MM and the nutritional markers will segregate among the haploids in the proportion of $4^{+}$to $2^{-}$. However, if the drug fails to induce crossing-over, the proportion will be $4^{+}$to $4^{-}$. This is due to the fact that the initial selection process limits the growth of auxotrophic $(-)$ diploids. The ratio of prototrophic to auxotrophic segregants is described by the Homozygosity Index (HI), in which an HI equal to or higher than 2.0 indicates the recombinogenic effect of the anticancer drugs (Figure 2). The recombinogenic potential of 

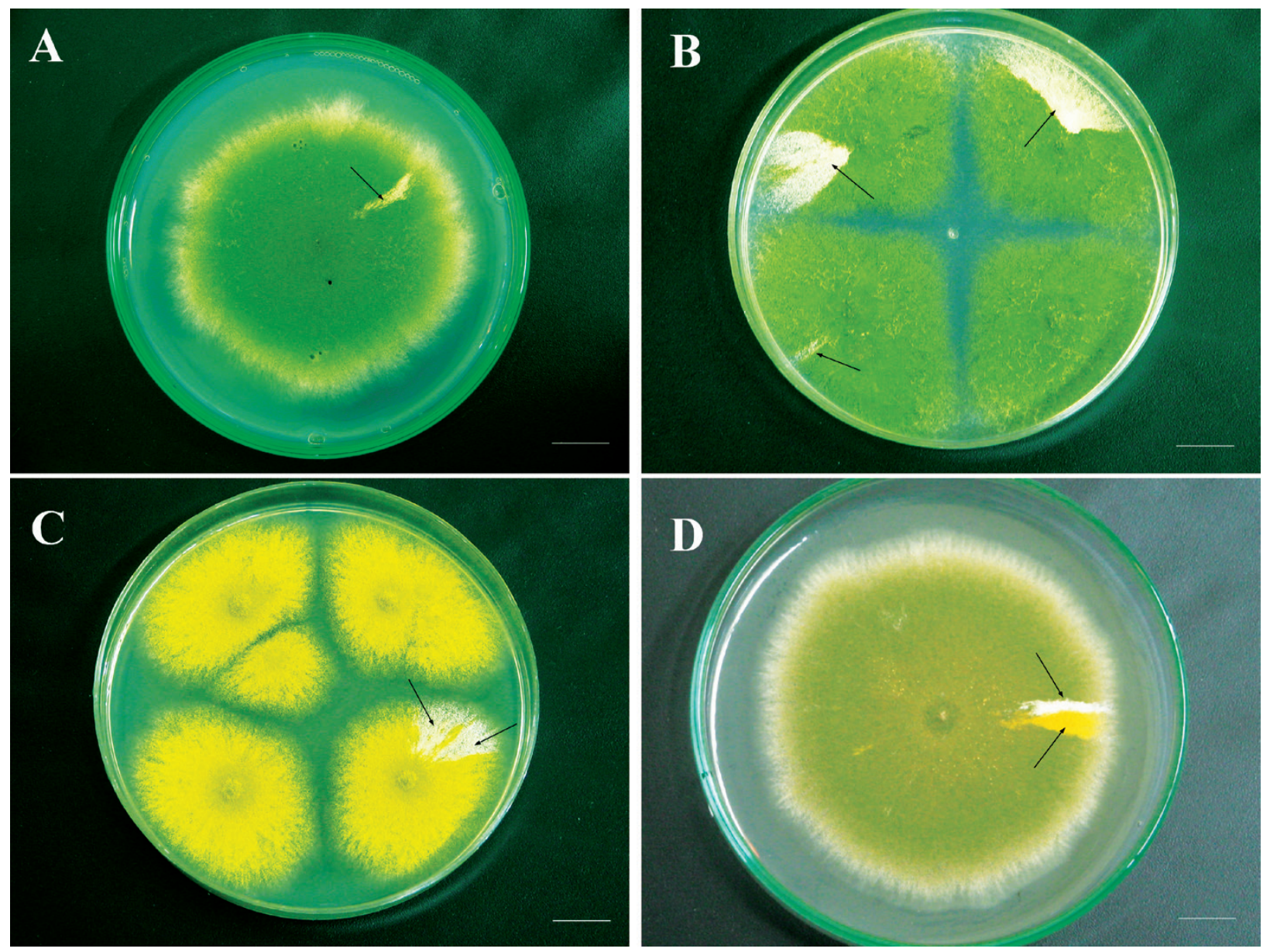

Figure 1 - Growth of A757//UT448 diploid strain in the absence of CPT or CPT-11 (control) (A). Diploids obtained after treatment with CPT $(17.4 \mu \mathrm{g} / \mathrm{mL})$ (B-C) and CPT-11 $(18 \mu \mathrm{g} / \mathrm{mL})$ (D). Arrows indicate the origin of mitotic segregants by the haploidization process. Bar $=5.0 \mathrm{~mm}$.

CPT and CPT-11 was assessed by comparing the homozygotization indexes of the nutritional markers with Yates corrected Chi-square test, Contingency Table, $\mathrm{p}<0.05$.

\section{RESULTS}

A minimum of 455 mitotic segregantes were recovered from each CPT treatment $\left(3.5 \mathrm{ng} \mathrm{mL}^{-1}, 10.5 \mathrm{ng}\right.$ $\mathrm{mL}^{-1}$ and $17.4 \mathrm{ng} \mathrm{mL}^{-1}$ ) in CM, after haploidization. CPT treated diploids produced a higher number of prototrophic than auxotrophic segregants, leading to HI values which were higher than 2.0 and significantly $(\mathrm{p}<0.05)$ different from the negative control, for most of the analyzed markers (Table II).
All CPT concentrations produced unstable diploids which, although heterozygous for the riboA1 and pyro $A 4$ genes, were homozygous for three other genes from linkage group I: $p a b a+, y$ and $b i+$. The homozygous condition of the nutritional pabaA124 and biAl genes was evidenced by the absence of auxotrophic segregants for these markers among the mitotic segregants derived from the unstable diploids, increasing HI values for genes pabaA124 and biAl (Table II). Results indicate that such diploids are recombinant for the centromere-paba interval from linkage group I.

Nine diploid segregants were recovered after treatment of the original diploid strain A757// 
TABLE II

Homozygotization Index (HI) values for markers from UT448//A757 diploid strain after treatment with camptothecin (CPT) and irinotecan (CPT-11).

\begin{tabular}{|c|c|c|c|c|c|c|c|c|c|c|c|c|c|c|c|c|}
\hline \multirow{3}{*}{ Markers $^{\mathrm{a}}$} & \multirow{2}{*}{\multicolumn{2}{|c|}{$\begin{array}{l}\text { negative } \\
\text { control }^{\text {b }}\end{array}$}} & \multirow{2}{*}{\multicolumn{2}{|c|}{$\begin{array}{l}\text { positive } \\
\text { control }^{\mathfrak{c}}\end{array}$}} & \multicolumn{6}{|c|}{ camptothecin } & \multicolumn{6}{|c|}{ irinotecan } \\
\hline & & & & & \multicolumn{2}{|c|}{$3.5 \mathrm{ng} \mathrm{mL}^{-1}$} & \multicolumn{2}{|c|}{$10.45 \mathrm{ng} \mathrm{mL}^{-1}$} & \multicolumn{2}{|c|}{$17.4 \mathrm{ng} \mathrm{mL}^{-1}$} & \multicolumn{2}{|c|}{$4.5 \mu \mathrm{g} \mathrm{mL} L^{-1}$} & \multicolumn{2}{|c|}{$9 \mu \mathrm{g} \mathrm{mL} L^{-1}$} & \multicolumn{2}{|c|}{$18 \mu \mathrm{g} \mathrm{mL^{-1 }}$} \\
\hline & $\mathrm{NS}^{\mathrm{d}}$ & $\mathrm{HI}$ & $\mathrm{NS}^{\mathrm{d}}$ & HI & $\mathrm{NS}^{\mathrm{d}}$ & HI & $\mathrm{NS}^{\mathrm{d}}$ & HI & $\mathrm{NS}^{\mathrm{d}}$ & HI & $\mathrm{NS}^{\mathrm{d}}$ & HI & $\mathrm{NS}^{\mathrm{d}}$ & HI & $\mathrm{NS}^{\mathrm{d}}$ & HI \\
\hline ribo+ & 129 & 1.4 & 194 & 1.6 & 368 & 1.6 & 313 & $2.2 *$ & 460 & $2.2 *$ & 254 & 1.0 & 297 & 1.2 & 444 & $2.0 *$ \\
\hline ribo & 92 & & 120 & & 225 & & 142 & & 211 & & 248 & & 247 & & 227 & \\
\hline paba+ & 126 & 1.3 & 209 & $2.0 *$ & 487 & $4.6^{*}$ & 387 & $5.7 *$ & 548 & $4.5^{*}$ & 256 & 1.0 & 297 & 1.2 & 445 & $2.0 *$ \\
\hline paba & 95 & & 105 & & 106 & & 68 & & 123 & & 246 & & 247 & & 226 & \\
\hline$b i+$ & 129 & 1.4 & 190 & 1.5 & 484 & $4.4 *$ & 391 & $6.1 *$ & 552 & $4.6^{*}$ & 248 & 1.0 & 284 & 1.1 & 436 & 1.9 \\
\hline$b i$ & 92 & & 124 & & 109 & & 64 & & 119 & & 254 & & 260 & & 235 & \\
\hline pyro + & 112 & 1.0 & 289 & $11.6 *$ & 323 & 1.2 & 319 & $2.3 *$ & 425 & 1.7 & 250 & 1.0 & 267 & 1.0 & 367 & 1.2 \\
\hline pyro & 109 & & 25 & & 270 & & 136 & & 246 & & 252 & & 277 & & 304 & \\
\hline
\end{tabular}

${ }^{\mathrm{a}}$ ribo $=$ riboflavin; $p a b a=p$-aminobenzoic acid; $b i=$ biotin; meth $=$ methionine and pyro $=$ pyridoxine. ${ }^{\mathrm{b}}$ Negative control, diploids did not treated with cisplatin, CPT nor CPT-11. ${ }^{c}$ Positive control, diploids treated with cisplatin $\left(0.9 \mu \mathrm{g} \mathrm{mL}{ }^{-1}\right.$. ${ }^{\mathrm{d}}$ Total number of mitotic segregants. ${ }^{*}$ Significantly different from negative control (Yates Corrected Chi Square, Contingency Table, $\mathrm{p}<0.05$ ).

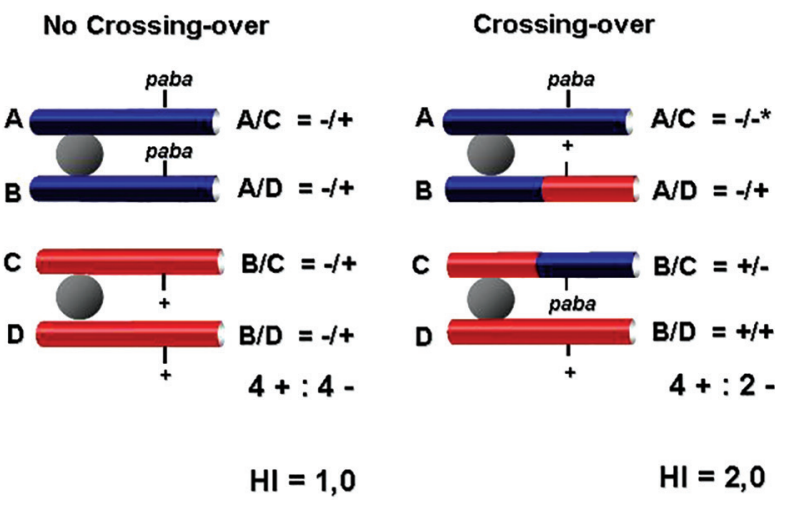

Figure 2 - Origin of heterozygous $(+/-$ and $-/+)$ and homozygous $(+/+)$ diploids caused by mitotic crossing-over between paba gene and centromere. $(*)$ Do not grow in MM (Pires and Zucchi 1994).

UT448 with $4.5 \mu \mathrm{g} \mathrm{mL}^{-1}, 9 \mu \mathrm{g} \mathrm{mL}^{-1}$ and $18 \mu \mathrm{g} \mathrm{mL}^{-1}$ CPT-11 concentrations. However, only the highest concentration tested $\left(18 \mu \mathrm{g} \mathrm{mL}^{-1}\right)$, corresponding to the maximal single chemotherapeutic dose (Kašuba et al. 2010), produced HI values higher than 2.0 and significantly $(p<0.05)$ different from the negative control HI values. The genetic markers from linkage groups I and IV of the diploids obtained with CPT-11 middle $\left(9 \mu \mathrm{g} \mathrm{mL}^{-1}\right)$ and low $(4.5 \mu \mathrm{g}$ $\mathrm{mL}^{-1}$ ) concentrations produced $\mathrm{HI}$ values less than 2.0 similar to the negative control.

\section{DISCUSSION}

The present study evaluated the genotoxic profiles of two topoisomerase-inhibitors, CPT and CPT-11, using the homozygotization assay of $A$. nidulans (Pires and Zucchi 1994). Diploid segregants obtained after treatment of the original diploid A757//UT448 strain with CPT at $3.5 \mathrm{ng} \mathrm{mL}^{-1}, 10.5 \mathrm{ng} \mathrm{mL}^{-1}$ and $17.4 \mathrm{ng} \mathrm{mL}^{-1}$ exhibited homozygosis for the markers from $A$. nidulans's linkage group I and HI values different $(\mathrm{p}<0.05)$ from the negative control. On the other hand, concerning the recombinogenic potential of CPT-11, a significant increase in the HI values was observed only following treatment with the highest CPT-11 concentration $\left(18 \mu \mathrm{g} \mathrm{mL}^{-1}\right)$, corresponding to the maximal single therapeutic dose (Kašuba et al. 2010). The lowest CPT-11 concentrations, corresponding to the recommended monotherapy (9 $\left.\mu \mathrm{g} \mathrm{mL}^{-1}\right)$ and combined therapy $\left(4.5 \mu \mathrm{g} \mathrm{mL}^{-1}\right.$ ) doses (Kašuba et al. 2010) were not recombinogenic under current experimental conditions. Contrasting results were obtained by Kašuba et al. (2010) who demonstrated a higher cytotoxic effect of CPT-11 at low $\left(9 \mu \mathrm{g} \mathrm{mL}^{-1}\right)$ rather than at high $\left(18 \mu \mathrm{g} \mathrm{mL}^{-1}\right)$ concentrations in Chinese hamster V79 cells.

Although CPT-11 is a prodrug, poorly active against Topo I, its active metabolite, 7-ethyl-10- 
hydroxycamptothecin (SN-38) is one of the most potent Topo I inhibitors. Previous studies comparing the molecular and cellular pharmacology of various CPT derivatives suggest that the CPT-11 clinical activity depends on its hydrolysis to $\mathrm{SN}-38$ by human liver carboxylesterase (Tanizawa et al. 1994). Therefore, the recombinogenic effect of CPT-11, observed in the present study only at the highest concentration, may be a result of a low conversion of CTP-11 to SN-38 in A. nidulans diploid cells.

Taking into account that a fraction of the drugstabilized Topo I cleavage complexes is converted into DNA damage upon collision with replication forks (Pommier et al. 2010, Huang et al. 2008, Arnaudeau et al. 2001), the recombinogenic effect of CPT and CPT-11, demonstrated here, may be associated with the recombinational repair of DNA strand breaks induced by these Topo I blockers.

Evidence that HR is required for the DSB repair after exposure to CPT comes from studies reporting on the high sensitivity to CPT exhibited by mutant cells for enzymes related to recombination repair: mammalian mutant cells for XRCC3 and Werner syndrome patients' cells, which are deficient in RecQ helicase (Agrelo et al. 2006, Ferrara and Kmiec 2004, van Waardenburg et al. 2004).

$\mathrm{HR}$ is an important mechanism involved in carcinogenesis which leads towards genetic loss through LOH when the recombinant sister chromatids segregate in mitosis to different daughter cells. HR is potentially able to induce the loss of the functional allele of a tumor suppressor gene in previously heterozygous cells. $\mathrm{LOH}$ in dermal neurofibromas has been shown to be frequently caused by mitotic recombination, resulting in homozygosity of the $\mathrm{NF} 1$ tumor suppressor gene mutant allele $\left(\mathrm{NF}^{-/-}\right)$. In addition, mitotic recombination within the region of $17 \mathrm{q}$ harboring the $N F 1$ gene was observed in $46 \%$ of plexform neurofibromas (Moynahan and Jasin 2010, Steinmann et al. 2009, Serra et al. 2001).

The recombinogenic effects of CPT and CPT11 , demonstrated here, as well as the ability of drugs to induce chromosomal aberrations (Sortibrán et al. 2006, Palitti et al. 1993) and DSB (Huang et al. 2008, Pommier 2006, Arnaudeau et al. 2001) imply in a possible risk of cancer patients developing secondary malignancies after chemotherapy with topoisomeraseinhibitors. In the normal cells of such patients, HR may induce aberrant genomic rearrangements, which may act as the primary step in the two-step model of carcinogenesis (Bishop and Shiestl 2002). Additionally, in pre-malignant cells, HR may induce genetic loss by LOH (Moynahan and Jasin 2010). Therefore, the clinical use of chemotherapeutic agents that induce HR and DNA fragmentation, such as CPT and CPT-11, must be weighed against the risk of the development of second malignancies.

Numerous reports have related the effect of high-dose chemotherapy and the pathogenesis of second neoplasms. Treatment-related factors are presumed to be responsible for the elevated risk of myelodysplastic syndrome, lung cancer, nonHodgkin's lymphoma and acute myeloid leukemia in patients treated with chemotherapy for distinct primary malignancies, such as hematologic and non-hematologic malignancies and Hodgkin's lymphoma (Swerdlow et al. 2011, Godley and Larson 2008, Leone et al. 2007). These studies show that there is a need for careful long-term monitoring of patients receiving chemotherapy for a primary condition, for the early detection and treatment of secondary cancers (Freeman et al. 2012, Papanikolaou et al. 2011, Swerdlow et al. 2011, Yamada et al. 1999).

\section{ACKNOWLEDGMENTS}

This research was supported by the Conselho Nacional de Desenvolvimento Científico e Tecnológico (CNPq). G.N.M. Esquissato was the recipient of a CNPq fellowship.

\section{RESUMO}

A recombinação mitótica é um processo com participação na carcinogênese e com capacidade de induzir perda 
genética através da perda da heterozigosidade. Os potenciais recombinagênicos de duas drogas anticancerígenas, camptotecina (CPT) e irinotecan (CPT-11), caracterizadas como inibidores da DNA-Topoisomerase I, foram avaliados no presente estudo, utilizando-se o ensaio de homozigotização, que avalia tanto a ocorrência da recombinação mitótica quanto a indução de homozigose, e a linhagem diplóide heterozigota de Aspergillus nidulans, A757//UT448. Três concentrações não-citotóxicas de CPT (3,5 $\mathrm{ng} \mathrm{mL} L^{-1}, 10,5 \mathrm{ng} \mathrm{mL}^{-1}$ e $17,4 \mathrm{ng} \mathrm{mL}^{-1}$ ) induziram tanto recombinação mitótica quanto homozigose gênica. Os tratamentos com CPT produziram diplóides homozigotos para genes nutricionais e de coloração de conídios, bem como Índices de Homozigotização (HI) significativamente diferentes do controle negativo. Em contraste, somente a maior concentração de CPT11 utilizada $\left(18 \mu \mathrm{g} \mathrm{mL}^{-1}\right)$, correspondente à dose única máxima utilizada em protocolos de quimioterapia, produziu valores de $\mathrm{HI}$ significativamente diferentes do controle negativo. Os efeitos recombinogênicos de ambos bloqueadores de Topoisomerase I foram associados ao reparo recombinacional de quebras no DNA induzidas pelos compostos CPT e CPT-11. Os antineoplásicos CPT e CPT-11 podem ser caracterizados como promotores de malignidades secundárias em pacientes com câncer após tratamento quimioterápico.

Palavras-chave: anticancerígenos, ensaio de homozigotização, recombinação homóloga, malignidades secundárias.

\section{REFERENCES}

AGRELO R ET AL. 2006. Epigenetic inactivation of the premature aging Werner syndrome gene in human cancer. Proc Natl Acad Sci 103: 8822-8827.

Arnaudeau C, Lundin C and Helleday T. 2001. DNA double-strand breaks associated with replication forks are predominantly repaired by homologous recombination involving an exchange mechanism in mammalian cells. J Mol Biol 307: 1235-1245.

ARNAUDEAU C, TENORIO MiRANDA E, JENSEN D AND HELlEDAY T. 2000. Inhibition of DNA synthesis is a potent mechanism by which cytostatic drugs induce homologous recombination in mammalian cells. Mutat Res 461: 221-228.

BERGEN LG AND MORRIS NR. 1983. Kinetics of the nuclear division cycle of Aspergillus nidulans. J Bacteriol 126: $155-160$.
BISHOP AJR AND SCHIESTL RH. 2002. Homologous recombination and its role in carcinogenesis. J Biomed Biotechnol 2: 75-85.

CARDoso RA, PIRES LT, ZuCCHI TD, ZuCCHI FD AND ZUCCHI TMAD. 2010. Mitotic crossing-over induced by two commercial herbicides in diploid strains of the fungus Aspergillus nidulans. Genet Mol Res 9: 231-238.

Castro-Prado J, Franco CCS, SAnT'AnNa JR, Miyamoto CT AND CASTRO-PRADO MAA. 2009. Recombinogenic activity of fluoxetine in Aspergillus nidulans. Drug Chem Toxicol 32: 338-343.

Domingues Zucchi T, Zucchi FD, Poli P, SoAres de Melo I AND ZUCCHI TMA. 2005. A short-term test adapted to detect the genotoxic effects of environmental volatile pollutants (benzene fumes) using the filamentous fungus Aspergillus nidulans. J Environ Monit 7: 598-602.

FERRARA L AND KMIEC EB. 2004. Camptothecin enhances the frequency of oligonucleotide-directed gene repair in mammalian cells by inducing DNA damage and activating homologous recombination. Nucleic Acids Res 32: 52395248.

FREEMAN JH, KWAN PWC AND WEBBer D. 2012. Large-cell neuroendocrine cancer of the colon following rituximabbased lymphoma treatment. Can J Gastroenterol 26: 12-13.

GODLEY LA AND LARSON RA. 2008. Therapy-related myeloid leukemia. Semin Oncol 35: 418-429.

HuAng M, MiaO ZE-Hong, ZHU H, CAI Yu-Jun, Lu W AND DING J. 2008. Chk1 and Chk2 are differentially involved in homologous recombination repair and cell cycle arrest in response to DNA double-strand breaks induced by camptothecins. Mol Cancer Therap 7: 1440-1449.

HÜsgen U, BÜtTner P, MÜLler U AND TUdZYNSKi P. 1999. Variation in Karyotype and Ploidy Level Among Field Isolates of Claviceps purpurea. J Phytopathol 47: 591-597.

KaŠUBA V, RozGaJ R, GAMULIN M AND TrošIĆ I. 2010. Assessment of cyto/genotoxicity of irinotecan in V79 cells using the comet, micronucleus, and chromosome aberration assay. Arh Hig Rada Toksikol 61: 1-9.

KIRPNICK Z, HOMISKI M, RUBITSKI E, REPNEVSKAYA M, Howlett N, Aubrecht J AND Schiestl RH. 2005. Yeast DEL assay detects clastogens. Mut Res 582: 116-134.

Leone G, Pagano L, Ben-Yehuda D and Voso MT. 2007. Therapy-related leukemia and myelodysplasia: susceptibility and incidence. Hematol J 92: 1389-1398.

LiN X AND Howell SB. 2006. DNA mismatch repair and p53 function are major determinants of the rate of development of cisplatin resistance. Mol Cancer Therapy 5: 1239-1247.

MiYAmoto CT, SANT'ANNA JR, FRANCO CCS AND CASTROPRADO MAA. 2007. Genotoxicity (mitotic recombination) of the cancer chemotherapeutic agents, cisplatin and cytosine arabinoside, in Aspergillus nidulans. Food Chem Toxicol 45: 1091-1095.

Moertel CG, Schutt AJ, Reitemeier RJ AND Hahn RG. 1972. Phase II study of camptothecin (NSC-100880) in the treatment of advanced gastrointestinal cancer. Cancer Chemother Rep 56: 95-101. 
MOYNAHAN ME AND JASIN M. 2010. Mitotic homologous recombination maintains genomic stability and suppresses tumorigenesis. Nat Rev Mol Cell Biol 11: 196-207.

PAlitti F, CORTES F, BASSI L, Di ChiARA D, FioRe M AND PINERO J. 1993. Higher G2 sensitivity to the induction of chromosomal damage in the CHO mutant EM9 than in its parental line AA8 by camptothecin, an inhibitor of DNA topoisomerase I. Mutat Res 285: 281-285.

Papanikolaou X, Barlogie B and Usmani SZ. 2011. Therapy-related myeloid malignancies in myeloma. Mediterr J Hematol Infect Dis 3: 1-5.

PAYNE M AND HICKSON ID. 2009. Genomic instability and cancer: lessons from analysis of Bloom's syndrome. Biochem Soc Trans 37: 553-559.

PIRES LTA AND ZUCCHI TMAD. 1994. A new method to detect potencial genotoxic agents using mitotic crossing over in diploid strains of Aspergillus nidulans. Braz J Genet 17: 371-376.

POMMIER Y. 2006. Topoisomerase I inhibitors: camptothecins and beyond. Nat Rev 6: 789-802.

POMMIER Y, LEO E, ZHANG HL AND MARCHAND C. 2010. DNA Topoisomerases and Their Poisoning by Anticancer and Antibacterial Drugs. Chem Biol 17: 412-433.

PunT CJAAND KoOPMAN M. 2008. Capecitabine and Irinotecan As First - Line Treatment of Advanced Colorectal Cancer. J Clinic Oncol 26: 1907-1908.

ROPER JA. 1952. Production of heterozygous diploids in filamentous fungi. Experientia 8: 14-15.

SAINTIGNY Y, MAKIENKO K, SWANSON C, EMOND MJ AND MONNAT RJ. 2002. Homologous Recombination Resolution Defect in Werner Syndrome. Mol Cel Biol 22: 6971-6978.

SANT'ANNA JR, MiYAMOTO CT, FRANCO CCS, MigUEL OG, CUNICO MM, CÔCCO LC, YAMAMOTO CI, JÚNIOR CC AND CAStro-Prado MAA. 2009. Genotoxicity of Achillea millefolium essential oil in diploid cells of Aspergillus nidulans. Phytother Res 23:231-235.

SANTOS PASR, SANT'ANNA JR, FRANCO CCS, ROSADA LJ, ESQUISSATO NM AND CASTRO-PRADO MAA. 2012. Induced mitotic homologous recombination by the babesicide imidocarb dipropionate in Aspergillus nidulans diploid cells. Genet Mol Res 11: 1810-1818.
Serra E, Rosenbaum T, Nadal M, Winner U, Ars E, Estival X AND LÁZARO C. 2001. Mitotic recombination effects homozygosity for NF1 germline mutations in neurofibromas. Nat Genet 28: 294-296.

SORTIBRÁN ANC, TÉLlEZ MGO AND RODRÍGUEZ-ARNAIZ R. 2006. Genotoxic profile of inhibitors of topoisomerases I (camptothecin) and II (etoposide) in a mitotic recombination and sex-chromosome loss somatic eye assay of Drosophila melanogaster. Mut Res 604: 83-90.

SteINMANN K, KLUWE L, FrIEDrich RE, MAUTNER ViCTORFELIX, COOPER DN AND KeHRER-SAWATZKI H. 2009. Mechanisms of loss of heterozygosity in neurofibromatosis type 1-associated plexiform neurofibromas. J Invest Dermatol 129: 615-621.

SWERDLOW AJ ET AL. 2011. Second cancer risk after chemotherapy for Hodgkin's lymphoma: a collaborative British cohort study. J Clinic Oncol 29: 4096-4104.

TANIZAWA A, FUJIMORI A, FUJIMORI Y AND POMMIER Y. 1994. Comparison of Topoisomerase I inhibition, DNA damage, and cytotoxicity of camptothencin derivatives presently in clinical trials. J Natl Cancer Inst 86: 836-842.

Tanizawa A, Kohn KW, Kohlhagen G, Leteurtre F AND POMMIER Y. 1995. Differential stabilization of eukaryotic DNA Topoisomerase I cleavable complexes by camptothecin derivatives. Biochem 34: 7200-7206.

VAN WAARDENBURG RCAM, DE JONG LA, VAN DELFT F, VAN EIJNDHOVEN MAJ, BOHLANDER M, BJORNSTI MA, BROUWER J AND SCHELlENS JHM. 2004. Homologous recombination is a highly conserved determinant of the synergistic cytotoxicity between cisplatin and DNA topoisomerases I poisons. Mol Cancer Therap 3: 393-402.

YAMADA T, SHINOHARA K, TAKEDA K, KAMED N, KATSUKI K, ARIYoshi K AND KAMEI T. 1999. Second lung adenocarcinoma after combination chemotherapy in two patients with primary non-Hodgkin's lymphoma. Japan J Clin Oncol 29: 226-228. 